\title{
Jurist-Diction
}

Volume 3 No. 5, September 2020

\section{Pemungutan Pajak Pertambahan Nilai Terhadap Barang Jasa Titip Dari Luar Negeri}

\author{
Stefani Gabriela Listijo
}

stefani.gabriela.listijo-2016@fh.unair.ac.id

Universitas Airlangga

\author{
How to cite: \\ Stefani Gabriela Listijo, \\ 'Pemungutan Pajak \\ Pertambahan Nilai Terhadap \\ Barang Jasa Titip Dari Luar \\ Negeri' (2020) Vol. 3 No. 5 \\ Jurist-Diction. \\ Histori artikel: \\ Submit 10 Juli 2020; \\ Diterima 14 Agustus 2020; \\ Diterbitkan 1 September 2020 \\ DOI: \\ 10.20473/jd.v3i5.21986
}

\begin{abstract}
Abstrak
Seiring dengan majunya teknologi dan mudahnya akses bepergian ke luar negeri, berkembang pula usaha jasa titip (personal shopper). Usaha jasa titip merupakan istilah kegiatan bisnis yang terdiri dari penjual yang bepergian ke luar negeri bertugas untuk membelikan barang titipan pembeli dan menerima keuntungan dari biaya jasa titip. Dalam praktiknya terdapat aspek perpajakan khususnya Pajak Pertambahan Nilai (PPN). Pendekatan masalah yang digunakan dengan menggunakan pendekatan peraturan perundang-undangan (statute approach) dan pendekatan konseptual (conceptual approach) untuk menelusuri legalitas barang jasa titip sebagai obyek PPN dan penegakan pemungutan PPN. Berdasarkan hasil penelitian barang jasa titip dari luar negeri merupakan barang kena pajak dan dikenai Bea Masuk dan Pajak Dalam Rangka Impor yang sudah mencakup PPN di dalamnya. Penegakan pemungutan PPN juga dapat dilakukan secara administratif maupun pidana, terlebih dalam penegakan secara administratif terdapat opsi upaya preventif dan represif. Tujuan penelitian ini adalah untuk mengedukasi pembaca mengenai PPN khususnya bagi wajib pajak yang melakukan praktik usaha jasa titip barang dari luar negeri.

Kata Kunci: Jasa Titip; Pemungutan; Pajak Pertambahan Nilai; Wajib pajak.
\end{abstract}

\section{Pendahuluan}

Untuk menjalankan suatu negara dibutuhkan lebih dari sekadar orang-orang untuk menjalankan roda pemerintahan, yaitu uang. Uang milik negara bersumber dari pajak yang disetor oleh masing-masing wajib pajak. Uang hasil pajak yang terkumpul ini merupakan penghasilan negara yang dimanfaatkan untuk pengeluaran umum dalam rangka membina keberlangsungan alat-alat negara, administrasi negara, lembaga negara, aset negara, pembangunan negara, dan seterusnya yang harus dibiayai dari penghasilan negara. Pajak merupakan iuran rakyat kepada kas negara berdasarkan amanat Pasal 23 Undang-Undang Dasar Negara Republik Indonesia 1945 yang sifatnya dapat dipaksakan dengan tanpa mendapat jasa-timbal 
(kontra-prestasi), yang langsung dapat ditunjukkan dan yang digunakan untuk membayar pengeluaran umum. ${ }^{1}$

Pajak di negara Indonesia digolongkan ke dalam dua kategori berdasarkan pemungutannya, yaitu pajak pusat dan pajak daerah. Pajak pusat adalah pajakpajak yang dikelola oleh pemerintah pusat yaitu oleh Direktorat Jenderal Pajak, Kementerian Keuangan. Hasil dari pungutan pajak pusat digunakan untuk membiayai belanja negara seperti pembangunan jalan, pembangunan sekolah, bantuan kesehatan dan lain sebagainya. Pajak daerah adalah pajak-pajak yang dikelola oleh Pemerintah Daerah baik di tingkat provinsi maupun kabupaten/ kota. ${ }^{2}$ Pajak-pajak pusat meliputi Pajak Penghasilan (PPh), Pajak Pertambahan Nilai (PPN), Pajak Pejualan Barang Mewah (PPnBM), Bea Materai, dan Pajak Bumi dan Bangunan (PBB). Sedangkan pajak daerah dibagi menjadi dua yaitu pajak provinsi dan pajak kabupaten/kota. Pajak Provinsi meliputi Pajak Kendaraan Bermotor, Bea Balik Nama Kendaraan Bermotor, Pajak Air Permukaan, dan Pajak Rokok. Pajak Kabupaten/Kota adalah Pajak Hotel, Pajak Restoran, Pajak Hiburan, Pajak Reklame, Pajak Penerangan Jalan, Pajak Mineral Bukan Logam dan Batuan, Pajak Parkir, Pajak Air Tanah, Pajak Sarang Burung Walet, Pajak Bumi dan Bangunan Perdesaan dan Perkotaan, dan Bea Perolehan Hak Atas Tanah dan/atau Bangunan.

Penggolongan pajak selanjutnya dapat digolongkan menjadi pajak langsung dan pajak tidak langsung. Pajak langsung adalah pajak yang dimaksudkan untuk dipikul oleh yang berkewajiban dan tidak dapat dilimpahkan kepada pihak lain, contohnya Pajak Penghasilan (PPh). Pajak tidak langsung merupakan pajak yang dimaksudkan untuk dilimpahkan oleh yang membayar kepada pemikul (konsumen), dalam arti bisa dilimpahkan atau dibebankan kepada pihak lain, di antaranya Pajak Pertambahan Nilai (PPN), Pajak Restoran, Pajak Hotel.

\footnotetext{
1 Rochmat Soemitro dalam Wirawan B. Ilyas, Richard Burton, Hukum Pajak (Edisi 6) (Salemba Empat 2014).[6].

2 DJP, 'Belajar Pajak' (DJP 2019) <https://www.pajak.go.id/id/jenis-pajak > , accessed 12 Agustus 2019.
} 
PPN merupakan pungutan di bawah kewenangan Direktorat Jenderal Pajak, Kementerian Keuangan. Namun perlu diketahui selain Direktorat Jenderal Pajak, Direktorat Bea \& Cukai, yang juga di bawah naungan Kementerian Keuangan menurut Peraturan Presiden Nomor 28 Tahun 2015, juga berwenang memungut PPN. Lebih jelasnya Direktorat Jenderal Bea dan Cukai adalah instansi pemerintah yang bertugas di bidang kepabeanan dan cukai yang berada di garis terdepan wilayah Republik Indonesia. Tugas dan fungsi DJBC adalah berkaitan erat dengan pengelolaan keuangan negara, antara lain memungut bea masuk berikut pajak dalam rangka impor (PDRI) meliputi (PPN Impor, PPh Pasal 22, PPnBM) dan cukai. Sebagaimana diketahui bahwa pemasukan terbesar (sering disebut sisi penerimaan) ke dalam kas negara adalah dari sektor pajak dan termasuk di dalamnya adalah bea masuk dan cukai yang dikelola oleh DJBC. ${ }^{3}$

Dalam praktinya, PPN hampir selalu dikaitkan dengan perdagangan yang berlangsung di dalam negeri maupun lintas negara. Sesuai definisi PPN di mana ada penyerahan barang kena pajak di daerah pabean (wilayah teritori Indonesia) maka itu menjadi obyek dari PPN. Maka barang yang masuk ke wilayah Indonesia berupa barang yang dibawa sepulang liburan dari luar negeri juga bisa jadi merupakan obyek PPN. Praktik membawa barang dari luar negeri untuk dijual lagi di Indonesia semakin marak dan seringkali dijumpai dengan istilah jasa titip.

Jasa titip merupakan istilah kegiatan bisnis di mana penjual yang bepergian ke luar negeri bertugas untuk membelikan barang titipan pembeli. Harga yang ditetapkan disertai dengan biaya jasa titip. Praktik bisnis jasa titip mulai marak dikarenakan mudahnya akses bepergian ke luar negeri yang didorong juga oleh majunya media sosial, sehingga siapa pun yang bepergian ke luar negeri dapat dengan mudah mengandalkan media sosialnya untuk memasarkan bisnis jasa titipnya. Pengusaha jasa titip yang bepergian ke luar negeri bergerak sebagai

3 BPPK, 'Bea Cukai Yang Tugasnya Digaris Depan Wilayah Republik Indonesia Melaksanakan Ketentuan Instansi Teknis' (BPPK Kemenkeu 2011) <https://bppk.kemenkeu.go.id/ $\mathrm{id} /$ berita-bc/18812-bea-cukai-yang-tugasnya-digaris-depan-wilayah-republik-indonesia-melaksanakan-ketentuan-instansi-teknis> accessed 12 Agustus 2019. 
perantara dan sebagai gantinya mendapat keuntungan dari biaya jasa titip. Pembeli pun diuntungkan karena tidak perlu mengeluarkan biaya dan usaha lebih untuk membeli barang tertentu. Bisnis jasa titip ini semakin diminati pembeli juga disebabkan oleh beberapa faktor, ingin mencari barang impor tetapi kesulitan mencari di dalam negeri, harga barang yang dijual oleh pengusaha jasa titip termasuk terjangkau dibandingkan produk sejenis dalam negeri, barang yang ditawarkan penjual beragam sehingga muncul keinginan mencoba barang baru dari luar negeri, dan sejenisnya.

Usaha jasa titip dapat dilakukan oleh siapa saja. Tidak sedikit yang awalnya hanya mencoba menerima titipan saat berlibur dan berujung menekuni usaha jasa titip ini secara lebih serius dan lebih profesional. Sehingga ketika pengusaha jasa titip yang mendedikasikan perjalanan ke luar negeri secara khusus untuk membuka peluang jasa titip, ada kecenderungan untuk mendapatkan pembeli sebanyakbanyaknya agar keuntungan yang diperoleh dapat mengganti biaya transportasi $\&$ akomodasi selama di luar negeri. Cara yang dilakukan untuk mencari pembeli beragam, mulai memasarkan barang dari keluarga, teman-teman, bahkan sampai memanfaatkan media sosial di mana peluang untuk memperluas pasar lebih meningkat. Sehingga pembeli tidak hanya dari orang-orang yang dikenal bahkan lebih luas lagi sampai dari orang-orang yang belum pernah dikenal sebelumnya. Adapun seorang pengusaha jasa titip yang tidak mau rugi akan membuat sistem di mana pembeli harus membayar belanjaan terlebih dahulu, baru barang yang dipesan dapat dibelanjakan, sehingga dengan sistem bayar di muka pengusaha jasa titip tidak sampai mengalami kerugian. ${ }^{4}$

Barang titipan yang dipesan oleh pembeli nantinya akan dibawa sebagai barang pribadi dari pengusaha jasa titip saat menumpangi pesawat. Perlu diketahui bahwa barang pribadi penumpang yang diperoleh dari luar daerah pabean (wilayah Indonesia) dengan nilai pabean paling banyak FOB USD500.00 (lima ratus United States Dollar) per orang untuk setiap kedatangan diberikan pembebasan

4 Adbis,'Maraknya Bisnis Jasa Titip di Sosial Media' (Aktual 2018) <https://aktual. co.id/2018/05/24/maraknya-bisnis-jasa-titip-jastip-di-sosial-media/> accessed 29 Desember 2019. 
bea masuk sesuai dengan yang tercantum dalam Peraturan Menteri Keuangan Nomor 203/PMK.04/2017 tentang Ketentuan Ekspor Dan Impor Barang Yang Dibawa Oleh Penumpang Dan Awak Sarana Pengangkut yang berlaku sejak 1 Januari 2018. Namun jika didapati barang pribadi penumpang melebihi batas nilai pabean, atas kelebihan tersebut dipungut bea masuk $10 \%$ (sepuluh persen) dan Pajak Dalam Rangka Impor (PDRI). Pajak Dalam Rangka Impor terdiri dari Pajak Pertambahan Nilai (PPN) 10\%(sepuluh persen) dan Pajak Penghasilan (PPh) 7,5\% (tujuh koma lima persen) jika mempunyai Nomor Pokok Wajib Pajak (NPWP), jika tidak mempunyai NPWP maka dikenakan tarif lebih tinggi yaitu $100 \%$ dari PPh yang semula 7,5\% (tujuh koma lima persen) menjadi 15\% (lima belas persen).

Dalam praktiknya pengusaha jasa titip yang tidak ingin penghasilannya berkurang tidak akan melaporkan kepada petugas bea \& cukai pada saat kedatangan di Indonesia. Umumnya jika terjadi pemeriksaan pengusaha jasa titip tidak akan memberitahukan tujuannya ke luar negeri adalah untuk berdagang bukan liburan, lalu berdalih barang titipan yang ia bawa hendak dipakai untuk pemakaian pribadi dan termasuk oleh-oleh. Hal ini kerap kali terjadi dikarenakan rendahnya kesadaran pengusaha jasa titip mengenai pentingnya membayar pajak. Serta stigma yang melekat bahwa pajak merupakan hal yang rumit dan menakutkan oleh masyarakat khususnya pengusaha jasa titip yang cenderung menghindar dari kewajiban membayar pajak. Di sisi lain, pengusaha jasa titip tidak sadar bahwa upaya untuk lari dari kewajibannya membayar pajak merupakan tindakan yang merugikan keuangan negara. Kepentingan umum harus menjadi korban dari oknum-oknum yang mengutamakan kepentingan pribadinya.

Anggapan inilah yang menghambat pertumbuhan pembangunan negara. Diharapkan dengan pengusaha jasa titip yang sadar akan kewajibannya untuk membayar pajak dapat meningkatkan perekonomian negara melalui pajak yang dibayar secara taat agar keseluruhan pemungutan pajak ini diharapkan dalam meningkatkan pendapatan pajak negara Indonesia. 


\section{Rumusan Masalah}

1. Legalitas dan karakteristik barang jasa titip dari luar negeri sebagai objek pajak pertambahan nilai.

2. Penegakan hukum terhadap pemungutan pajak pertambahan nilai barang jasa titip dari luar negeri.

\section{Metode Penelitian}

Penelitian ini merupakan penelitian hukum (legal research) yang sesuai dengan karakter khas dari ilmu hukum (jurisprudence) sebagai suatu disiplin yang sui generis. ${ }^{5}$ Penelitian ini dapat dikategorikan ke dalam tipe reform-oriented research karena mengevaluasi pemungutan Pajak Pertambahan Nilai di bidang usaha jasa titip yang sedang berlaku dan merekomendasikan perubahan terhadap peraturan yang dibutuhkan dalam upaya pengembangan hukum.

\section{Subyek Dan Obyek Pajak Pertambahan Nilai}

Karakteristik PPN yaitu pajak tidak langsung di mana pemikul beban pajak dengan penanggungjawab atas pembayaran pajak berada pada pihak yang berbeda, pembeli atau penerima jasalah yang menjadi pemikul beban pajak, sedangkan penjual barang atau jasa bertindak sebagai pihak yang bertanggungjawab atas pembayaran PPN. Maka terdapat dua pihak yaitu pembeli dan pengusaha jasa titip, dengan ini pembeli berkedudukan menjadi subyek jasa titip karena pembeli yang menjadi pemikul beban Pajak Pertambahan Nilai yang timbul dalam transaksi jasa titip sedangkan pengusaha jasa titip berkedudukan sebagai perantara yang menerima pembayaran Pajak Pertambahan Nilai dari pembeli dan pada akhirnya membayarkan Pajak Pertambahan Nilai tersebut.

Obyek Pajak Pertambahan Nilai diatur dalam Pasal 4 ayat (1) Undang-Undang Pajak Pertambahan Nilai yang menerangkan mengenai penyerahan yang dikenakan Pajak Pertambahan Nilai, bahwa "Pajak Pertambahan Nilai dikenakan atas:

5 Peter Mahmud, Penelitian Hukum (Edisi Revisi) (Kencana Prenada Media Grup 2017). 
a. penyerahan Barang Kena Pajak di dalam Daerah Pabean yang dilakukan oleh pengusaha;

b. impor Barang Kena Pajak;

c. penyerahan Jasa Kena Pajak di dalam Daerah Pabean yang dilakukan oleh pengusaha;

d. pemanfaatan Barang Kena Pajak Tidak Berwujud dari luar Daerah Pabean di dalam Daerah Pabean;

e. pemanfaatan Jasa Kena Pajak dari luar Daerah Pabean di dalam Daerah Pabean;

f. ekspor Barang Kena Pajak Berwujud oleh Pengusaha Kena Pajak;

g. ekspor Barang Kena Pajak Tidak Berwujud oleh Pengusaha Kena Pajak; dan

h. ekspor Jasa Kena Pajak oleh Pengusaha Kena Pajak."

\section{Karakteristik Barang Jasa Titip Dari Luar Negeri Sebagai Obyek Pajak Pertambahan Nilai}

Perlu diperhatikan bahwa barang yang dibawa dari luar negeri bukanlah kategori barang mewah karena barang mewah berada dalam lingkup kajian Pajak Penjualan Atas Barang Mewah (PPnBM) yaitu pajak yang dikenakan atas konsumsi Barang Kena Pajak yang tergolong mewah di dalam Daerah Pabean. Barang yang tergolong mewah dan dikenai PPnBM adalah barang yang bukan merupakan barang kebutuhan pokok, dikonsumsi oleh masyarakat tertentu, dikonsumsi oleh masyarakat berpenghasilan tinggi, dikonsumsi hanya untuk menunjukkan status atau kelas sosial. Barang mewah sebagai contoh tas desainer, sepatu desainer, baju desainer, dan lain-lain yang bernilai ekonomis tinggi hingga puluhan bahkan ratusan juta rupiah. Sedangkan barang jasa titip dari luar negeri yang dimaksud bukan merupakan barang mewah. Umumnya barang jasa titip luar negeri dapat dikonsumsi oleh masyarakat secara luas seperti contoh baju, kosmetik, aksesoris, suplemen, perlengkapan rumah tangga, bahkan obat yang umumnya masih dapat dikategorikan untuk memenuhi kebutuhan pokok.

Dalam hal jasa titip, barang titipan dibawa oleh pengusaha jasa titip dari luar negeri ke daerah Pabean dan selanjutnya diserahkan atau dikirimkan kepada pembeli. Barang hasil titipan dari luar negeri tersebut ditujukan untuk dikonsumsi oleh pembeli dan tidak untuk dijual kembali. Pada dasarnya barang jasa titip dari luar negeri yang dibawa oleh pengusaha jasa titip bukan merupakan barang 
pribadi karena peruntukannya dari awal untuk dijadikan obyek jual beli. Sehingga barang jasa titip dari luar negeri memiliki karakter dan memenuhi unsur untuk dikategorikan sebagai obyek yang dikenai Pajak Pertambahan Nilai. Dalam hal ini terpenuhi unsur penyerahan Barang Kena Pajak yang dibawa oleh pengusaha jasa titip dari luar Daerah Pabean ke dalam Daerah Pabean kepada pembeli yang telah melakukan perjanjian jual beli dengannya, dengan ini menjadikan barang jasa titip dari luar negeri obyek dari Pajak Pertambahan Nilai.

\section{Tata Cara Pemungutan Pajak Pertambahan Nilai Terhadap Barang Jasa Titip dari Luar Negeri}

Pengawasan dan pelayanan atas ekspor maupun impor barang yang dibawa oleh penumpang dan awak sarana pengangkut dilaksanakan di kawasan pabean yang sepenuhnya berada di bawah pengawasan Direktorat Jenderal Bea dan Cukai namun dapat dilakukan di tempat lain setelah mendapatkan persetujuan Kepala Kantor Pabean menurut Pasal 26 Peraturan Menteri Keuangan Nomor 203/PMK.04/2017 Tentang Ketentuan Ekspor Dan Impor Barang Yang Dibawa Oleh Penumpang Dan Awak Sarana Pengangkut. Barang bawaan penumpang yang masuk ke Daerah Pabean disebut juga barang impor bawaan penumpang yang terdiri atas :

a. barang pribadi penumpang yang dipergunakan atau dipakai untuk keperluan pribadi termasuk sisa perbekalan (personal use); dan/atau

b. barang impor yang dibawa oleh penumpang selain barang pribadi (nonpersonal use).

Barang impor bawaan yang dimaksud merupakan selain barang pribadi (nonpersonal use ) merupakan barang yang jumlah, jenis, dan sifatnya tidak wajab untuk keperluan pribadi dan/atau dibawa untuk keperluan industri, perusahaan, toko, institusi, atau keperluan lain selain keperluan pribadi. Barang jasa titip yang dibawa oleh pengusaha jasa titip termasuk dalam kategori selain abrang pribadi (nonpersonal use) karena dipergunakan untuk keperluan lain selain keperluan pribadi yaitu untuk diperdagangkan kembali dan memeproleh untung dari itu. Pejabat Bea dan Cukai berdasarlan Pasal 7 berwenang untuk menetapkan kategori barang 
impor bawaan penumpang berdasarkan manajemen risiko. Manajemen risiko yang dimaksud yaitu dengan mempertimbangkan profil penumpang, profil barang impor yang dibawa oleh penumpang, data importasi penumpang, dan/atau data lainnya. Barang impor bawaan penumpang merupakan barang yang tiba bersama dengan penumpang saat masuk ke Daerah Pabean.

Terhadap barang jasa titip dari luar negeri dikategorikan sebagai barang impor yang berlaku tarif bea masuk atas barang bersangkutan sesuai dengan ketentuan perundang-undangan mengenai pembebanan tarif bea masuk umum sebesar $10 \%$ (sepuluh persen) dan nilai pabean ditetapkan berdasarkan keseluruhan nilai pabean barang impor. Contoh perhitungan bea masuk dan Pajak Dalam Rangka Impor atas impor barang yang dibawa oleh penumpang yang merupakan pengusaha jasa titip berdasarkan Peraturan Direktur Jenderal Bea Dan Cukai Nomor : PER-09/BC/2018 adalah sebagai berikut :

Penumpang A datang dari Singapura dengan menggunakan pesawat udara membawa 30 buah lipstick, 20 buah bedak wajah, 10 buah tas pesta dan pakaian yang berasal dari Indonesia sebanyak 20 helai. Sesuai dengan bukti pembelian (invoice) diketaui bahwa harga masing-masing barang tersebut adalah :

- lipstick seharga USD 10/buah;

- bedak wajah seharga USD 200/buah;dan

- tas pesta seharga USD 100/buah.

Perhitungan :

a. Secara jumlah dan jenis barang, barang tersebut jika dikategorikan sebagai barang hasil jasa titip dan diberikan pembebasan bea masuk sebesar FOB USD 500, sehingga nilai pabean yang dikenakan Bea Masuk dan Pajak Dalam Rangka Impor sebesar USD 300.

b. Total FOB lipstick, bedak wajah, dan tas pesta adalah :

$\begin{array}{llll}\text { - lipstick } & : \text { 30xUSD 10 }= & \text { USD } & 300 \\ \text { - bedak wajah } & : \text { 20xUSD 20= } & \text { USD } & 400 \\ \text { - tas pesta } & : \text { 5xUSD 20 }= & \text { USD } & 100+\end{array}$


c. Pungutan Bea Masuk dan Pajak Dalam Rangka Impor

Sebelum menghitung Bea Masuk dan Pajak Dalam Rangka Impor, nilai pabean harus ditetapkan terlebih dahulu dalam cost,insurance, freight (CIF) yang totalnya merupakan nilai deminimis, sehingga perlu penambahan unsur Freight(F) atau biaya kargo sebesar USD 10 (perkiraan berdasarkan data obyektif dan terukur) dan insurance (I) sebesar USD 5 (perkiraan berdasarkan data obyektif dan terukur). Kurs sebesar Rp 14.000,00.

- Bea Masuk : 10\% x Nilai Impor

: 10\% x (Nilai Pabean+Nilai Deminimis)

: $10 \% \times(300+(\mathrm{F}+\mathrm{I}))$

$: 10 \% \times(300+15)$

: USD 31,5 = Rp 441.000,00

- PPN $\quad: 10 \% \times$ Nilai Impor

$: 10 \% \times 315$

: USD 31,5 = Rp 441.000,00

- PPh(NPWP) : 7,5\% x Nilai Impor

$: 7,5 \% \times 315$

: USD $23.63=\operatorname{Rp} 330.820,00$

Maka total pajak dari belanjaan A yang membelanjakan barang jasa titip dari Singapur ini total sebesar USD 86.63 atau sebesar Rp 1.212.820,00. Artinya jika dihitung per barang dengan total barang impor adalah 55 barang, rata-rata total Bea Masuk dan Pajak Dalam Rangka Impor per barangnya adalah sebesar Rp 22.051,27 dengan Pajak Pertambahan Nilai mengambil bagian sebesar Rp 8.018,18.

Pajak Pertambahan Nilai yang pada dasarnya berdasarkan segi pemungutannya, Pajak Pertambahan Nilai dikategorikan sebagai pajak pusat karena dipungut oleh pemerintah pusat dan berfungsi untuk mengisi anggaran Negara dan mengatur kebijakan ekonomi sosial umumnya pemungutan dilakukan oleh Direktorat Jenderal Pajak, namun dalam hal barang jasa titip 
dari luar negeri pemungutan Pajak Pertambahan Nilai dilakukan sekaligus oleh Direktorat Jenderal Bea dan Cukai yang berwenang untuk menetapkan besaran Bea Masuk dan Pajak Dalam Rangka Impor untuk barang jasa titip yang masuk ke area Pabean.

\section{Penegakan Hukum Terhadap Wajib PajakAtas Barang Jasa Titip Dari Luar Negeri}

Penegakan hukum terhadap wajib pajak atas barang jasa titip dari luar negeri terdiri dari 2(dua) kategori yaitu penegakan hukum administrasi dan penegakan hukum pidana. Dalam sanksi administrasi setiap tindakan penegakan hukum dilakukan oleh Pejabat Tata Usaha Negara tanpa perlu melalui proses peradilan karena tujuan diberlakukannya sanksi administrasi semata-mata untuk menghentikan tindakan pelanggaran itu sendiri. Dalam penegakan administrasi pun dapat diupayakan dengan penegakan hukum preventif(untuk mencegah pelanggaran terjadi) dan penegakan hukum represif (dalam hal sudah terjadi pelanggaran).

Dalam hal penegakan hukum pidana, sanksi pidana merupakan senjata pamungkas (terakhir) atau ultimum remedium yang diterapkan apabila didapati sanksi administratif dirasa belum cukup untuk mencapai tujuan penegakan hukum dan rasa keadilan dalam masyarakat. Umumnya jika terjadi tindak pidana dalam bidang perpajakan, maka badan peradilan yang memiliki kompetensi untuk menyelesaikan sengketa adalah Pengadilan Negeri.

Penegakan hukum terkait perpajakan jasa titip sudah mulai menjadi perhatian Bea Cukai karena ditemukan kecenderungan penghindaran pajak dari pengusaha jasa titip menambah beban dalam penegakan hukum perpajakan. Belum adanya kesadaran dari pengusaha jasa titip akan kewajiban perpajakannya menambah beban tersendiri dalam penegakan hukum perpajakan.

\section{Analisis Pemungutan Dan Penegakan Hukum Terhadap Barang Jasa Titip Dari Luar Negeri}

Dalam penyelenggaraan kegiatan kenegaraan, tentunya diperlukan biaya yang besar sebagaimana dianggarkan di dalam Anggaran Pendapatan Belanja Negara 
(APBN). Tentunya pengeluaran dari negara bergantung pada jumlah pemasukan negara. Salah satu potensi pemasukan negara saat ini adalah pajak.

Pajak memiliki kaitan erat dengan hubungan antara negara dengan subyek pajak maupun hubungan antara negara dengan obyek pajak, sehingga demi tercapainya sistem pemungutan pajak yang berkeadilan maka kewenangan negara untuk memungut pajak perlu bertumpu pada beberapa asas-asas pemungutan di antaranya: ${ }^{6}$

1. Asas Domisili (asas tempat tinggal)

- Negara berhak mengenakan pajak atas seluruh penghasilan Wajib Pajak yang bertempat tinggal di wilayahnya, baik penghasilan yang berasal dari dalam maupun dari luar negeri. Asas ini berlaku untuk Wajib Pajak dalam negeri.

- Subyek yang dapat dikenai pajak adalah orang atau badan yang berdomisili di negara tersebut.

- Obyek yang dapat dikenai pajak adalah penghasilan yang diperoleh subyek pajak dimanapun penghasilan itu diperoleh.

2. Asas Sumber

- Negara berhak mengenakan pajak atas penghasilan yang bersumber di wilayahnya tanpa memperhatikan tempat tinggal Wajib Pajak.

- Subyek yang dapat dikenai pajak adalah orang atau badan yang memiliki sumber penghasilan tersebut di manapun mereka berada.

- Obyek yang dapat dikenai pajak adalah hanya yang keluar dari sumber penghasilan yang terletak di negara tersebut.

3. Asas Kebangsaan

- Pengenaan pajak dihubungkan dengan kebangsaan suatu negara. Misalnya pajak bangsa asing di Indonesia dikenakan pada setiap orang yang bukan berkebangsaan Indonesia yang bertempat tinggal di Indonesia. Asas ini berlaku utuk Wajib Pajak luar negeri.

- Subyek yang dapat dikenai pajak adalah orang-orang yang berkebangsaan negara tersebut di manapun ia berada.

- Obyek yang dapat dikenai pajak adalah seluruh penghasilan di manapun diperoleh orang tersebut.

Dari berbagai asas pemungutan di atas dapat diketahui bahwa dalam usaha jasa titip, maka asas pemungutan yang digunakan adalah asas domisili atau asas tempat tinggal. Pengusaha jasa titip adalah orang yang bertepat tinggal di Indonesia, bepergian ke luar negeri untuk melakukan kegiatan jasa titip, dari kegiatannya ia membawa

6 Mardiasmo, Perpajakan (Andi Offset 2003).[7]. 
pulang barang titipan pembeli di Indonesia. Sehingga negara Indonesia berhak mengenakan pajak atas penghasilan dari pengusaha jasa titip karena pengusaha jasa titip selaku subyek yang berdomisili di negara Indonesia dan penghasilan dari usaha jasa titipnya selaku obyek yang dapat dikenai pajak.

Ada pula asas pemungutan pajak yang dikenal dengan The Four Cannons atau The Four Maxims yang dibahas dalam buku An Inquiry Into The Nature And Causes Of The Wealth Of Nations oleh Adam Smith diuraikan sebagai berikut: ${ }^{7}$

\section{Equality}

Pembebanan pajak di antara subyek pajak hendaknya seimbang dengan kemampuannya, yaitu seimbang dengan penghasilan yang dinikmatinya di bawah perlindungan pemerintah. Dalam hal equality negara tidak diperbolehkan mengadakan diskriminasi di antara sesama Wajib Pajak.

2. Certainty

Pajak yang dibayar oleh Wajib Pajak harus jelas dan tidak mengenal kompromi (not arbitrary). Dalam asas ini kepastian hukum yang diutamakan adalah mengenai subyek pajak, obyek pajak, tarif pajak, dan ketentuan mengenai pembayarannya.

3. Convenience of Payment

Pajak hendaknya dipungut pada saat yang paling baik bagi Wajib Pajak, yaitu saat sedekat-dekatnya dengan saat diterimanya penghasilan/keuntungan yang dikenakan pajak.

4. Economic of Collections

Pemungutan pajak hendaknya dilakukan sehemat dan seefisien mungkin, jangan sampai biaya pemungutan pajak lebih besar daripada penerimaan pajak itu sediri karena tidak ada artinya pemungutan pajak kalau biaya yang dikeluarkan lebih besar dari penerimaan pajak yang akan diperoleh.

Jika dikaitkan dengan asas pemungutan dari Adam Smith, maka pemungutan Pajak Pertambahan Nilai terhadap barang jasa titip dari luar negeri memenuhi asas equality karena pembebanan PPN seimbang dengan penghasilan yang dinikmatinya. Tarif PPN termasuk dalam tarif proporsional yaitu dengan persentase yang tetap $10 \%$ (sepuluh persen), tetapi jumlah pajak yang terutang akan berubah secara proporsional/sebanding dengan dasar pengenaan pajaknya. Semakin banyak barang jasa titip yang dibawa dari luar negeri, semakin tinggi penghasilan yang akan didapat, maka semakin tinggi nilai pembebanan PPN yang dikenakan dari

7 Erly Suandy, Hukum Pajak (Edisi Kedua) (Salemba Empat 2005).[27-28]. 
persentase yang ditetapkan pada saat penghitungan pajaknya.

Dalam hal asas certainty terdapat kepastian hukum dari pemerintah dengan adanya Peraturan Direktur Jenderal Bea Dan Cukai Nomor : PER-09/BC/2018 yang memuat tata cara penghitungan pajak yang dapat diterapkan dalam kasus jasa titip dari luar negeri meskipun tata cara penghitungannya tidak secara spesifik untuk barang jasa titip dari luar negeri. Namun perlu diperhatikan bahwa pengaturan tentang tata cara penghitungan pajak barang jasa titip dari luar negeri perlu disosialisasikan dalam wujud yang lebih sederhana, mudah dipamahi, dan terlebih mudah diaskes oleh masyarakat awam mengingat praktik usaha jasa titip terhitung usaha yang baru dan pelaku usaha jasa titip umumnya berasal dari masyarakat awam yang baru dalam bidang impor.

Selanjutnya dari segi convenience of payment diusahakan agar pajak dipungut pada saat paling baik bagi Wajib Pajak yaitu saat sedekat-dekatnya dengan saat diterimanya penghasilan/keuntungan yang dikenakan pajak. Hal ini sudah dilakukan dalam praktik di mana saat terdekat dengan diterimanya penghasilan/keuntungan adalah sesaat setelah pengusaha jasa titip memasuki Daerah Pabean sebelum barang jasa titip diserahkan/dikirimkan kepada pembeli, sehingga petugas Bea Cukai yang berwenang di area inilah yang melakukan kewenangan pemungutan pajaknya, dalam hal ini ketika kedatangan di bandara Indonesia. Hal ini dipermudah juga dengan disediakannya customs declaration atau Pemberitahuan Impor Barang Khusus (PIBK) sejak dari pesawat sebelum memasuki Daerah Pabean. Jadi bagi pengusaha jasa titip yang membawa barang jasa titip melebihi batas yang ditentukan dapat mengisi formulir pemberitahuan pabean atau customs declaration agar memudahkan proses pemungutan pajak serta mengurangi upaya penghindaran pajak.

Usaha jasa titip banyak diminati pembeli disebabkan oleh beberapa faktor: ingin mencari barang impor tetapi kesulitan mencari di dalam negeri, harga barang yang dijual oleh pengusaha jasa titip termasuk terjangkau dibandingkan produk sejenis dalam negeri, barang yang ditawarkan penjual beragam sehingga muncul keinginan mencoba barang baru dari luar negeri, dan sejenisnya. Dari hasil penelusuran lebih lanjut, Bea Cukai mengungkapkan modus penghindaran 
kewajiban perpajakan dengan menggunakan jasa titip yang merupakan cara favorit bagi masyarakat Indonesia untuk membeli barang tanpa harus bepergian ke luar negeri. ${ }^{8}$

Terhitung hingga 25 September 2019, Bea Cukai Soekarno-Hatta telah melakukan penindakan terhadap 422 kasus pelanggaran terhadap para pengusaha jasa titip dengan destinasi paling sering antara lain Bangkok, Singapura, Hong Kong, Guangzhou, Abu Dhabi, dan Australia. Sebanyak 75\% kasus jasa titip didominasi oleh barang-barang berupa pakaian, berikutnya kosmetik, tas, sepatu, dan barangbarang bernilai ekonomis lainnya. Dari penindakan tersebut Bea Cukai berhasil menyelamatkan hak negara sekitar Rp 4 miliar. Barang titipan dari luar negeri cenderung dijual dengan harga lebih murah dibanding harga pasaran disebabkan adanya penghindaran kewajiban perpajakan karena pada umumnya pengusaha jasa titip masih banyak yang belum mengerti tentang perpajakan terkait jasa titip. Sehingga yang banyak terjadi adalah pengusaha jasa titip tidak melakukan kewajibannya pada saat ketibaan di Daerah Pabean yaitu melaporkan barang impor yang dibawanya dalam customs declarations atau Pemberitahuan Impor Barang Khusus (PIBK) .

Penegakan hukum terkait perpajakan jasa titip sudah mulai menjadi perhatian Bea Cukai karena sudah terbukti adanya 422 kasus hasil temuan Bea Cukai dan berhasil diselesaikan. Hal ini berdampak baik terhadap pemasukan negara karena dengan gencarnya pengawasan yang dilakukan oleh Bea Cukai, negara dihindarkan dari adanya kerugian akibat pengusaha jasa titip yang melakukan penghindaran pajak. Adanya kecenderungan penghindaran pajak dari pengusaha jasa titip menambah beban dalam penegakan hukum perpajakan karena belum adanya kesadaran dari pengusaha jasa titip akan kewajiban perpajakannya. Sosialisasi terkait aspek perpajakan jasa titip perlu semakin digencarkan demi memudahkan penegakan hukum perpajakan jasa titip, mengingat bidang usaha jasa titip masih terhitung baru dan berpotensi memberikan pemasukan tambahan bagi negara.

\footnotetext{
8 Antara, 'Bea Cukai Bakal Awasi Transaksi Jastip Lewat Media Sosial' (Tempo, 2019) $<$ https://bisnis.tempo.co/read/1253845/bea-cukai-bakal-awasi-transaksi-jastip-lewat-media-sosial $>$ accessed 29 Desember 2019.
} 
Kedepannya perlu adanya regulasi yang secara spesifik mengatur terkait usaha jasa titip dalam rangka upaya reformasi pajak (tax reform). Reformasi pajak dilakukan manakala terdapat peraturan perpajakan yang sudah tidak sesuai lagi dengan perkembangan zaman, terutama tidak agi sesuai dengan perkembangan ekonomi yang selama ini berlaku di Indonesia. Hal ini dikarenakan peraturan yang ada yang dapat diterapkan untuk pengusaha jasa titip masih merupakan pengaturan untuk importir. Importir umumnya merupakan badan usaha yang bergerak dan berpengalaman di bidang impor, beda halnya dengan pengusaha jasa titip sebagai importir pemula yang umumnya tidak memiliki pengalaman dalam bidang impor. Dari segi kuantitas barang jasa titip yang dibawa tidak sebanding dengan importir yang menggunakan jasa pengiriman khusus. Barang jasa titip dari segi kuantitas tidak sebanyak itu sehingga masih bisa dibawa bersama dengan pengusaha jasa titip dalam barang bawaannya. Hal ini membuat kesadaran akan kewajiban perpajakan menjadi rendah karena merasa dirinya tidak memiliki kewajiban perpajakan akibat menganggap kuantitas barang titipan sedikit. Namun hal ini tidak boleh dibiarkan karena pada praktiknya, usaha jasa titip semakin menjamur. Usaha jasa titip semakin banyak karena permintaan juga banyak dan usaha ini berarti terbukti bernilai ekonomis bahkan dapat dijadikan sumber penghasilan bagi pengusaha tersebut. Artinya pajak yang dapat dipungut oleh negara dari bidang usaha jasa titip ini tidak boleh dianggap remeh karena berpotensi menjadi pemasukan tambahan bagi negara. Dengan adanya reformasi pajak diharapkan beban pajak akan semakin adil dan wajar, sehingga di satu pihak mendorong wajib pajak melaksanakan dengan kesadaran kewajibannya membayar pajak dan di lain pihak menutup peluang-peluang yang selama ini terbuka bagi wajib pajak untuk menghindari pajak. Sehingga tercapai ekstensifikasi dan intensifikasi pengenaan dan pemungutan pajak importir menjadi lebih ekstensif dan intensif yaitu pengusaha jasa titip. Sistem pajak diharapkan menjadi lebih sederhana dan mudah dimengerti oleh setiap wajib pajak dengan adanya reformasi pajak dalam hal ini di bidang usaha jasa titip. 


\section{Kesimpulan}

Barang jasa titip dari luar negeri merupakan Barang Kena Pajak dan dikenakan Bea Masuk dan Pajak Dalam Rangka Impor. Pajak Dalam Rangka Impor terdiri dari Pajak Pertambahan Nilai (PPN) 10\%(sepuluh persen) dan Pajak Penghasilan (PPh) 7,5\% (tujuh koma lima persen) jika mempunyai Nomor Pokok Wajib Pajak (NPWP), jika tidak mempunyai NPWP maka dikenakan tarif lebih tinggi yaitu $100 \%$ dari PPh yang semula 7,5\% (tujuh koma lima persen) menjadi 15\% (lima belas persen). Pajak Pertambahan Nilai merupakan salah satu komponen dalam Pajak Dalam Rangka Impor yang tidak dapat dipisahkan. Pajak Pertambahan Nilai sendiri adalah pajak yang dikenakan atas penyerahan barang kena pajak atau jasa kena pajak yang dilakukan oleh pengusaha kena pajak di dalam daerah pabean atau atas impor barang kena pajak. Direktorat Jenderal Bea dan Cukai yang berada di bawah dan bertanggungjawab kepada Menteri Keuangan dan dipimpin oleh Direktur Jenderal Bea dan Cukai berwenang menyelenggarakan perumusan dan pelaksanaan kebijakan di bidang pengawasan, penegakan hukum, pelayanan dan optimalisasi penerimaan negara di bidang kepabeanan dan cukai.

Penegakan hukum terhadap wajib pajak atas barang jasa titip dari luar negeri terdiri dari 2(dua) kategori yaitu penegakan hukum administrasi dan penegakan hukum pidana. Dalam sanksi administrasi setiap tindakan penegakan hukum dilakukan oleh Pejabat Tata Usaha Negara tanpa perlu melalui proses peradilan karena tujuan diberlakukannya sanksi administrasi semata-mata untuk menghentikan tindakan pelanggaran itu sendiri. Dalam penegakan administrasi pun dapat diupayakan dengan penegakan hukum preventif (untuk mencegah pelanggaran terjadi) dan penegakan hukum represif (dalam hal sudah terjadi pelanggaran). Dalam hal penegakan hukum pidana, sanksi pidana merupakan senjata pamungkas (terakhir) atau ultimum remedium yang diterapkan apabila didapati sanksi administratif dirasa belum cukup untuk mencapai tujuan penegakan hukum dan rasa keadilan dalam masyarakat. Umumnya jika terjadi tindak pidana dalam bidang perpajakan, maka badan peradilan yang memiliki kompetensi untuk menyelesaikan sengketa adalah Pengadilan Negeri.Penegakan hukum terkait 
perpajakan jasa titip sudah mulai menjadi perhatian Bea Cukai karena ditemukan kecenderungan penghindaran pajak dari pengusaha jasa titip menambah beban dalam penegakan hukum perpajakan. Belum adanya kesadaran dari pengusaha jasa titip akan kewajiban perpajakannya menambah beban tersendiri dalam penegakan hukum perpajakan.

\section{Daftar Bacaan}

\section{Buku}

Erly Suandy, Hukum Pajak, Edisi Kedua (Salemba Empat 2005).

Mardiasmo, Perpajakan (Andi Offset 2003).

Peter Mahmud, Penelitian Hukum (Edisi Revisi) (Kencana Prenada Media Grup 2017).

Rochmat Soemitro dalam Wirawan B. Ilyas, Richard Burton, Hukum Pajak (Edisi 6) (Salemba Empat 2014).

\section{Laman}

Adbis,'Maraknya Bisnis Jasa Titip di Sosial Media' (Aktual, 2018) <https:// aktual.co.id/2018/05/24/maraknya-bisnis-jasa-titip-jastip-di-sosial-media/> accessed 29 Desember 2019.

Antara, 'Bea Cukai Bakal Awasi Transaksi Jastip Lewat Media Sosial' (Tempo, 2019) < < <ttps://bisnis.tempo.co/read/1253845/bea-cukai-bakal-awasitransaksi-jastip-lewat-media-sosial> accessed 29 Desember 2019.

BPPK, 'Bea Cukai Yang Tugasnya Digaris Depan Wilayah Republik Indonesia Melaksanakan Ketentuan Instansi Teknis' (BPPK Kemenkeu, 2011) $<$ https:// bppk.kemenkeu.go.id/id/berita-bc/18812-bea-cukai-yang-tugasnya-digarisdepan-wilayah-republik-indonesia-melaksanakan-ketentuan-instansi-teknis> accessed 12 Agustus 2019.

DJP, 'Belajar Pajak' (DJP, 2019) <https://www.pajak.go.id/id/jenis-pajak> accessed 12 Agustus 2019. 